\title{
Investigation of solid waste characteristics in field-scale landfill test cells
}

\author{
Top S. ${ }^{1}$, Akkaya G.K. ${ }^{2}$, Demir A. ${ }^{3}$, Yıldız Ş. ${ }^{4}$, Balahorli V. ${ }^{5}$, Aykut N.O. ${ }^{5}$ and Bilgili M.S. ${ }^{1{ }^{*}}$ \\ ${ }^{1}$ Yildiz Technical University, Faculty of Civil Engineering, Department of Environmental Engineering, 34220, Esenler, Istanbul, Turkey \\ ${ }^{2}$ Necmettin Erbakan University, Faculty of Engineering and Architecture, Deparment of Environmental Engineering, 42140 Meram, \\ Konya, Turkey \\ ${ }^{3}$ Istanbul Environmental Management Industry and Trade Inc. (ISTAC), Istanbul, Turkey \\ ${ }^{4}$ Istanbul Applied Gas and Energy Technologies Research Engineering Indsutry Trade Inc. (UGETAM), İstanbul, Turkey \\ ${ }^{5}$ Yildiz Technical University, Faculty of Civil Engineering, Department of Geomatic Engineering, 34220 Esenler, Istanbul, Turkey \\ Received: 11/12/2018, Accepted: 19/01/2019, Available online: 23/01/2019 \\ *to whom all correspondence should be addressed: e-mail: mbilgili@yildiz.edu.tr \\ https://doi.org/10.30955/gnj.002982
}

\section{Abstract}

This paper presents the results of an experimental study carried out in field-scale test cells in order to determine the effect of aeration and leachate recirculation on waste decomposition rate, solid waste characteristics, landfill gas composition and settlement in the landfill body. Four landfill test cells with the dimensions of $20 \mathrm{~m} \times 40 \mathrm{~m} \times 5 \mathrm{~m}$ were constructed in Komurcuoda Sanitary Landfill, Istanbul. Solid wastes representing Istanbul Asian side waste characteristics were landfilled in the test cells and they were operated simulating anaerobic (AN1), leachate recirculated anaerobic (AN2), semi-aerobic (A1) and aerobic landfilling (A2) methods. Alternative landfilling methods for accelerating solid waste stabilization in landfills were investigated by means of solid waste characteristics (elemental analysis, $\mathrm{pH}$, moisture content, TOC, TKN, C/N ratio, volatile solid content (VS), biochemical methane potential (BMP), and stability index (SI) analysis), landfill gas components $\left(\mathrm{CH}_{4}, \mathrm{CO}_{2}, \mathrm{O}_{2}\right.$, and $\left.\mathrm{H}_{2} \mathrm{~S}\right)$, temperature variations in landfill body, and landfill settlement. The study indicated that aeration and leachate recirculation accelerate biodegradation rate. Higher rates of MSW biodegradation eventually provide reduction in the contaminant life span of the landfill by achieving a high waste volume reduction in a relatively short duration than anaerobic test cells, decrease the cost of long term monitoring incurred with post-closure of landfill sites. In case of impossibility of aerobic landfilling based on the results of the cost benefit analysis, it was stated out that semi-aerobic landfilling technology is also a viable method in shortening the stabilization time and accelerating the landfill gas production.

Keywords: Aerobic landfill, anaerobic landfill, semiaerobic landfill, leachate recirculation, landfill gas composition, settlement.

\section{Introduction}

Sanitary landfilling is the most cost effective, least polluting and safest method in the alternative solid waste disposal methods (Bashir et al., 2010; Davis and Cornwell, 2008; Aziz et al., 2010). Landfilling allows the organic part of the waste to be decomposed to inert and stabilized materials under controlled conditions by the activity of aerobic and anaerobic bacteria. In a conventional landfill, waste degrades via fermentation processes under anaerobic conditions. Anaerobic degradation in conventional landfills occurs as a consequence of a series of metabolic interactions among various groups of microorganisms (Mohee et al., 2008). Physical, chemical, and biological processes occur within a conventional landfill body to promote the anaerobic degradation of solid waste and result with the production of leachate, landfill gas and biologically stable solids for a very long time (Cossu and Rossetti, 2003).

Since anaerobic decomposition of solid waste in conventional landfills is a slow process, there has been an increased emphasis on bioreactor landfill technology in recent years in order to increase the waste degradation rate, provide a reduction in landfill emissions in a shorter period of time, and treat leachate in situ (Pohland and AlYousfi, 1994; Reinhart, 1996; Townsend et al., 1996; Pohland and Kim, 2000; Mehta et al., 2002; Reinhart et al., 2002; Chan et al., 2002; Price et al., 2003; Demir et al., 2004; Bilgili et al., 2006; Shou-liang et al., 2008). One of the most widely used methods for increasing solid waste degradation in landfills is leachate recirculation. Leachate recirculation not only improves the leachate quality but also extensively shortens the stabilization time (Pohland and Kim, 1999; Mehta et al., 2002; Chan et al., 2002; Demir et al., 2004; Wang et al., 2006; Bilgili et al., 2007).

There has been an increasing interest in aerobic and semiaerobic landfilling operations as a means of improving the quality of leachate and landfill gas during recent years. 
Many pilot-scale and field-scale studies have been recently undertaken on this subject (Hudgins and Harper, 1999; Shimaoka et al., 2000; Read et al., 2001a; Das et al., 2002; Themelis and Kim, 2002; Cossu and Rossetti, 2003; Borglin et al., 2004; Tong et al., 2015; Ritzkowski et al., 2016; Townsend et al., 2015).

Aerobic biodegradation is an environmentally sound approach consisting of an accelerated degradation of heterogeneous organic matter by a mixed microbial population in a moist, warm, aerobic environment under controlled conditions (Mohee et al., 2008). The primary goal of the aerobic landfill system is to achieve optimum in situ waste treatment and volume reduction (and ultimately stabilization) through aerobic degradation. In contrast to anaerobic bioconversion, this reaction is strongly exothermic. Studies of aerobic biodegradation processes have demonstrated that the organic parts of the refuse can be degraded in a relatively short time compared with anaerobic degradation (Hudgins and Harper, 1999; Shimaoka et al., 2000; Read et al., 2001a; Read et al., 2001b; Themelis and Kim, 2002; Cossu et al., 2003; Borglin et al., 2004; Bilgili et al., 2007; Rich et al., 2008)

Overall, beyond many advantages of aerobic landfilling technology, this approach is not a cost-effective system. Another alternative in solid waste disposal to increase the stabilization rate and shorten the decomposition time is semi-aerobic landfilling. This method not only provides the same advantages of aerobic landfilling but also save cost in a significant amount (Yasushi and Masataka, 1997; Onay and Pohland, 1998; Dong et al., 2000; Kim and Yang, 2002; Qifei et al., 2008).

The aim of the existing research is to investigate the anaerobic, semi-aerobic and aerobic bioreactor landfilling technologies as alternative methods for enhancing solid waste stabilization in landfills comparing with conventional landfilling method. The paper summarizes the results of field-scale solid waste bioreactor landfill cells to quantify the effect of aeration (forced and natural) and leachate recirculation on the rate of biological degradation of the solid waste at Komurcuoda Landfill Site (an engineered landfill), which is located in Istanbul, Turkey. The dimensions of the test cells constructed were $20 \mathrm{~m} \times 40 \mathrm{~m} \times 5 \mathrm{~m}$. Alternative landfilling methods for accelerating solid waste stabilization in landfills are investigated by the means of i) solid waste characteristics, ii) landfill gas components, iii) temperature variation in landfill body and iv) landfill settlement.

\section{Material method}

\subsection{Aerobic and anaerobic landfill test cells}

Four identical field-scale test cells simulating anaerobic (AN1), anaerobic leachate recirculated (AN2), semiaerobic (A1) and aerobic (A2) landfills were simultaneously operated for a period of about 450 days in order to investigate the effect of alternative landfilling methods used for accelerating the waste decomposition rate and minimizing the long-term environmental impacts. Test cells were constructed with the dimensions of
$20 \times 40 \times 5 \mathrm{~m}(\mathrm{~B} \times \mathrm{L} \times \mathrm{H})$ in Komurcuoda landfill site $\left(41^{\circ} 8^{\prime} 41^{\prime \prime} \mathrm{N}, 2^{\circ} 22^{\prime} 21^{\prime \prime} \mathrm{E}\right)$ in Istanbul, Turkey. The average composition of solid wastes landfilled at the test cells was $44 \%$ organic (food and yard wastes), $8 \%$ paper, $6 \%$ glass, $6 \%$ metals, $5 \%$ plastic, $5 \%$ textile, $9 \%$ nylon, $8 \%$ diaper, and $9 \%$ ash and others (Demir et al., 2004). A detailed schematic view of the test cells is depicted in Figure 1.

The impermeable liner of the test cells was constructed acording to the technical standards explained in the "Regulation for the Landfilling of Wastes" of Ministry of Environment and Forestry. Leachate collection was achieved by perforated pipes $(\varnothing 150 \mathrm{~mm})$ in aerobic (A2) and anaerobic (AN1, AN2) test cells. In the semi-aerobic test cell (A1) the leachate collection pipe $(\varnothing 500 \mathrm{~mm})$ was also used to provide aeration. In the aerobic test cell (A2) aeration pipes were constructed and forced aeration was provided with a compressor and blower system. The aeration was regulated by measuring $\mathrm{CO}_{2}, \mathrm{CH}_{4}$ ve $\mathrm{O}_{2}$ content of the landfill gas. To avoid the anaerobic conditions in the landfill body in aerobic reactor, $\mathrm{O}_{2}$ content of the landfill gas was hold in the range of $5-15 \%$ (Binner et al., 2003).

The discharged leachate from the test cells was collected in storage tanks and recirculated to A1, A2 and AN2 test cells. Landfill gas was collected via the perforated pipes, which were located in the center of each cell. Temperature probes were located at four different depths $(1.0,1.5,2.0$, and $3.0 \mathrm{~m})$ in the landfill body to measure temperature variations in each test cell.

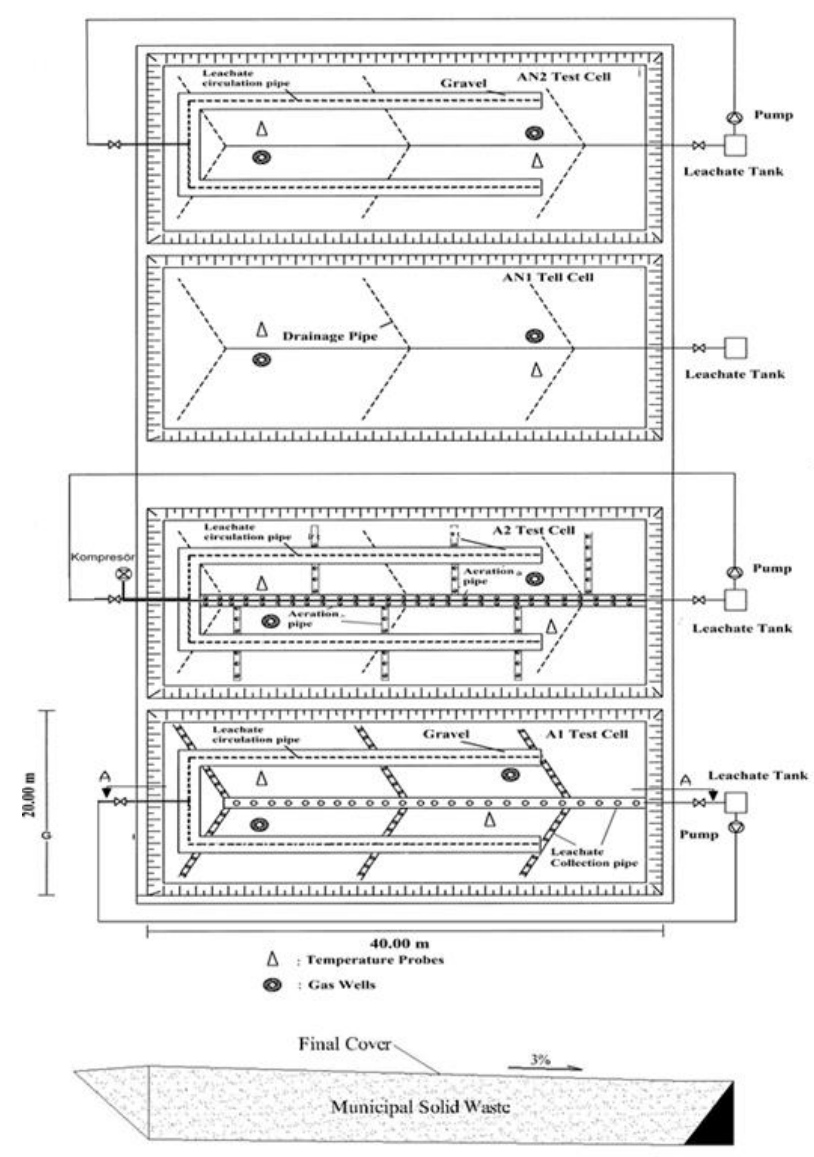

Figure 1. A detailed schematic view of the test cells 


\subsection{Experimental study}

\subsubsection{Solid waste analysis}

Solid waste analysis was performed on fresh solid waste samples at the beginning of the operation. Samples were taken every 200 days by excavation for analysis after landfilling of solid wastes.

Solids analysis requires finely ground homogeneous samples. The samples were ground in a grinder to pass a $1.5 \mathrm{~mm}$ screen after drying. Thereafter, $\mathrm{pH}$, moisture content, organic matter content, total Kjeldahl nitrogen (TKN), total organic carbon (TOC), C/N ratio, volatile solids (VS) analysis were realized according to the recommended standard procedures for the examination of solid waste followed in the Methods of Soil Analysis (1996).

Moisture content was evaluated by drying in a forced draft oven at $103 \stackrel{\circ}{\circ}$ for 24 h. A 100 g subsample was incinerated at 550 o $\mathrm{C}$ for $2 \mathrm{~h}$ in order to estimate the volatile solids and ash contents. The $\mathrm{pH}$ of the sample were measured using a 1:10 (v:v) sample to deionized water extract. The ground sample $10 \mathrm{~g}$. was mixed with $100 \mathrm{ml}$ of deionized water and allowed to equilibrate for 30 min with occasional stirring with a magnetic stirrer. The resulting solution was filtered and $\mathrm{pH}$ was measured by Jenway 3040 Ion Analyser.

\subsubsection{Stability index (SI)}

Stability Index assay is used to determine the stability of the end products biodegraded in the aerobic test cells. The stability index (SI) of the end product was measured using the procedure described by lannotti et al. (1993). A sample of material was obtained and standardized for particle size $(<10 \mathrm{~mm})$ and moisture content $(35 \%)$ and incubated (37 으) for $16 \mathrm{~h}$ under aerobic conditions to build the microbial populations to an active standard level. A $60 \mathrm{~g}$ sample of the incubated material was placed in an aerated respirometric flask at constant temperature in a water bath $(37 \stackrel{\circ}{\circ})$ for $1 \mathrm{~h}$. The aeration source was removed and oxygen concentration inside the flask was monitored every $5 \mathrm{~min}$ for a period of $1 \mathrm{~h}$. The oxygen consumption rate $\left(\mathrm{mg}\left(\mathrm{O}_{2}\right) / \mathrm{g}\right.$ (volatile solids)/h) was calculated from oxygen utilization in the test flask. This rate depends on the amount of substrate availability under standard conditions of particle size, moisture, temperature, aeration and incubation. Greater substrate availability results in higher oxygen demand indicating that the sample is biologically unstable, i.e. the sample is continuing to degrade.

\subsubsection{Biochemical methane potential (BMP)}

Organic fraction of the classified wastes was ground to passthrough a $1.5 \mathrm{~mm}$ screen after drying for $24 \mathrm{~h}$ at $103{ }^{\circ} \mathrm{C}$, and the BMP test was performed on these waste samples. The organic content of solid waste samples was transformed to easily degradable form by prehydrolizing of $10 \mathrm{~g}$ sample at $120 \mathrm{o} \mathrm{C}$ for $2 \mathrm{~h}$ at $1 \mathrm{~atm}$ in $0.1 \mathrm{~N}$ sodium hydroxide $(\mathrm{NaOH})$ solution before fermentation (Marticorena et al., 1993). Mineral solution (20 ml) (Öztürk, 1993) and $30 \mathrm{ml}$ anaerobic sludge were added to the pretreated waste samples. Samples were incubated in
$500 \mathrm{~mL}$ serum bottles at $35 \stackrel{\circ}{ } \mathrm{C}$ and thoroughly mixed using magnetic stirrers. Carbondioxide $\left(\mathrm{CO}_{2}\right)$ component of the produced biogas was held in $1 \mathrm{~N} \mathrm{NaOH}$ solution, and the quantity of $\mathrm{CH}_{4}$ was measured. After gas generation was completed ( 30 days), $\mathrm{CH}_{4}$ production rate per unit dry weight were evaluated. BMP test was performed on fresh solid waste samples at the beginning of the operation. After landfilling of solid wastes, samples were taken every 200 days for BMP test from AN1 and AN2 test cells.

\subsubsection{Landfill gas analysis}

$\mathrm{CH}_{4}, \mathrm{CO}_{2}, \mathrm{O}_{2}$ ve $\mathrm{H}_{2} \mathrm{~S}$ analysis were implemented in landfill gas generated in aerobic and anaerobic test cells by Geotech GA2000 Plus Model landfill gas measurement device.

\subsubsection{Topographical measurements}

Topographic measurements were performed in order to determine the covered area and estimated boundries of each test cell. In addition, the elevations based on the specific points of each cell have been identified. The same measurements were repeated at the later stages of the study in order to determine the amount of settlement. Volumetric difference between the measurements was defined as the amount of settlement. Measurements were carried out by Nikon DTM-332 total station device and its equipments.

\section{Results and discussion}

\subsection{Solid waste characteristics}

\subsubsection{Elemental analysis}

Organic matter which constitutes the major component of municipal solid waste can be degraded by aerobic and anaerobic processes in landfills. Municipal solid wastes consist of a large number of organic compounds that are impossible to be determined individually. Therefore, such methods as elemental analysis has been developed in order to determine the largest component of the organic matter. This material can be used to determine the degradability of solid waste in landfills. Elemental analysis results of the raw solid waste samples before landfilling are given in Table 1.

The molecular formula of the organic matter content of the landfilled solid wastes is determined as $\mathrm{C}_{3.7} \mathrm{H}_{5.7} \mathrm{O}_{3.2}$. This statement can be used as $\mathrm{C}_{4} \mathrm{H}_{6} \mathrm{O}_{3}$. When compared with ultimate \% analysis of various components of the MSW given by Tchobanaglous et al. (1993), it is observed that molecular formula of the raw solid waste simulates mixed food wastes. Also, Themelis and Kim (2002) approximated the molecular composition of mixed food and plant wastes as $\left(\mathrm{C}_{6} \mathrm{H}_{10} \mathrm{O}_{4}\right)_{x}$ which is comparable to our results.

Table 1. Elemental analysis of raw solid waste samples

\begin{tabular}{ccccc}
\hline Sample & $\mathbf{C}(\%)$ & $\mathbf{H}(\%)$ & $\mathbf{O}(\%)$ & Molecular Formula \\
\hline A1 & 41.1 & 5.2 & 53.7 & $\mathrm{C}_{3.4} \mathrm{H}_{5.2} \mathrm{O}_{3.4}$ \\
\hline $\mathrm{A} 2$ & 43.4 & 5.8 & 50.8 & $\mathrm{C}_{3.6} \mathrm{H}_{5.8} \mathrm{O}_{3.2}$ \\
\hline AN1 & 46 & 6.2 & 47.8 & $\mathrm{C}_{3.8} \mathrm{H}_{6.2} \mathrm{O}_{3}$ \\
\hline AN2 & 44.7 & 5.7 & 49.6 & $\mathrm{C}_{3.7} \mathrm{H}_{5.7} \mathrm{O}_{3.1}$ \\
\hline Mean Value & 44.3 & 5.7 & 50.0 & $\mathrm{C}_{3.7} \mathrm{H}_{5.7} \mathrm{O}_{3.2}$ \\
\hline
\end{tabular}


After the determination of the initial composition of organic matter the elemental analysis performed on samples taken from the body of each cell and the organic matter decomposition were evaluated according to this analysis during the operational period. The variation of $\mathrm{C}$ content in solid waste samples taken from aerobic and anaerobic test cells by 200 days intervals are given in Figure 2.

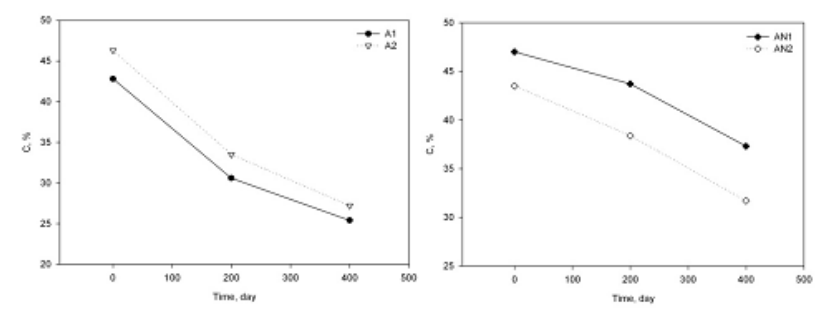

Figure 2. Variations of C content of solid waste in aerobic and anaerobic test cells

As can be seen from Figure 2, the initial C content of organic matter in all test cells was around $45 \%$. Finally, C content of the waste samples taken from $A 1$ and $A 2$ test cells was onserved as $25.4 \%$ and $27.2 \%$, respectively. Thus, it is indicated that the $\mathrm{C}$ removel for both $\mathrm{A} 1$ and $\mathrm{A} 2$ test cells was $41 \%$ after 400 days of operation. The $C$ removal rate for AN1 and AN2 test cells was determined as $21 \%$ and $27 \%$, respectively.

Table 2. The variation of waste characteristics in aerobic and anaerobic test cells

\begin{tabular}{cccccccccc}
\hline Sample & Day & $\mathbf{p H}$ & $\begin{array}{c}\text { Moisture } \\
\text { content (\%) }\end{array}$ & $\begin{array}{c}\text { VS content } \\
\text { (\%) }\end{array}$ & $\begin{array}{c}\text { Ash content } \\
\text { (\%) }\end{array}$ & TOC (\%) & TKN (\%) & C/N & $\begin{array}{c}\text { (C/N)final/ } \\
\text { (C/N)initial }\end{array}$ \\
\hline Raw waste & 0 & 6.2 & 68 & 73.1 & 26.9 & 38.7 & 2.2 & 17.6 & \\
\hline A1 & 200 & 7.8 & 62 & 58.6 & 41.4 & 26.4 & 2.8 & 9.4 & 0.43 \\
\hline & 400 & 7.5 & 65 & 49.4 & 50.6 & 23.4 & 3.1 & 7.5 & \\
\hline A2 & 200 & 7.4 & 64 & 51.1 & 48.9 & 24.2 & 3.2 & 7.6 & 0.33 \\
\hline AN1 & 400 & 8.1 & 67 & 44.7 & 53.3 & 20.7 & 3.6 & 5.7 & \\
\hline AN2 & 200 & 7.2 & 59 & 67.2 & 32.8 & 34.1 & 2.4 & 14.2 & \\
\hline & 400 & 7.6 & 52 & 60.1 & 39.9 & 30.5 & 2.7 & 11.3 & \\
\hline & 200 & 7.7 & 62 & 63.5 & 36.5 & 31.7 & 2.1 & 15.1 & \\
\hline & 400 & 7.5 & 63 & 56.4 & 43.6 & 26.1 & 2.4 & 10.9 &
\end{tabular}

The optimum $\mathrm{pH}$ range for microbial activity is generally between 6 and 8 . Bacteria prefer a pH between 6 and 7.5, while fungi thrive a wider range of $\mathrm{pH}$ levels than bacteria. If the $\mathrm{pH}$ drops below 6 , microorganisms especially bacteria dies and decomposition slows. If the $\mathrm{pH}$ reaches to 9, nitrogen is converted to ammonia and becomes unavailable for organisms. Thus, the decomposition of solid waste slows. $\mathrm{pH}$ values available for the aerobic degradation of solid waste are near neutral values. Nakasaki et al. (1993) determined an optimum $\mathrm{pH}$ range of 7-8 while testing the $\mathrm{pH}$ dependency of active microorganisms in the composting process. Demir et al. (2001) concluded from their study of aerobic composting of anise wastes that $\mathrm{pH}$ increases to approximately 8.5 after stabilization. The $\mathrm{pH}$ value of raw waste landfilled in the test cells was determined as 6.1. It is observed that $\mathrm{pH}$ values of solid waste samples increased by time indicating stabilization in the test cells. Final pH values of solid waste
The degradation of solid waste in landfills is generally explained as a first order reaction. Thus, the calculated first order rate constant $\left(k\right.$, year $\left.{ }^{-1}\right)$ for $C$ removal in $A 1, A 2$, AN1, and AN2 test cells was 0.50, 0.50, 0.20. and 0.28, respectively. According to these results, both aerobic and semi-aerobic systems are found to be the rapid systems for solid waste decompositon. The obtained $k$ values for AN1 and AN2 test cells can be used to calculate the required time to reach the degradation rate of $A 1$ and $A 2$ test cells. Accordingly, the necessary time to achieve this degradation rate was determined as 1660 and 1160 days for AN1 and AN2 test cells, respectively. Thus, it can be concluded that aerobic decompostion of solid waste significantly shortens the required time for waste stabilization in landfills. Also, leachate circulation can be used as an alternative for enhancing the waste degradation rate when compared with conventional landfills.

\subsection{2. $\mathrm{pH}$, Moisture content, VS content, TOC, TKN, C/N ratio}

Solid waste analysis such as $\mathrm{pH}$, moisture content, TKN, TOC, $\mathrm{C} / \mathrm{N}$ ratio and $\mathrm{VS}$ content were realized on the raw waste samples and samples axcavated from test cells during the study. The results of these analysis are given in Table 2. Evaluations of the obtained experimental results are given below. samples for A1, A2, AN1 and AN2 test cells were determined to be $7.5,8.1,7.6$ and 7.5 , respectively. It can be concluded from these results that optimum $\mathrm{pH}$ values required for biological degradation were achieved in aerobic test cells in a shorter time, indicating higher degradation rate in aerobic conditions. No considerable change was observed in $\mathrm{pH}$ values of solid waste samples from aerobic and anaerobic test cells depending on leachate recirculation.

Microorganisms require water to assimilate nutrients, metabolize new cells and reproduce. Therefore, moisture content affects microbial activity and thus influence temperature and rate of decomposition. In addition, moisture can affect the composition of the microbial population. During the aerobic degradation of solid waste, for moisture content below $\% 40$ the microbial activity decreases. Furthermore, anaerobic conditions can exist because of blocked pore space above $\% 60$ moisture 
(Epstein, 1997). Also, optimum moisture content of the wastes is very important for degradation rate, stabilization time and leachate quality under anaerobic conditions.

The moisture content of the solid waste samples landfilled in the aerobic and anaerobic test cells was determined as $\% 68$. This value is consistent with the result concluded by Demir et al. (2004) and also in the range presented by Epstein (1997) for compostable solid wastes. No significant change was observed in moisture contents of solid waste samples in $A 1$, $A 2$ and AN2 test cells because of leachate recirculation. However, it can be seen from Table 3 that moisture content of solid waste samples in AN1 test cell decreased by time.

The volatile solid content of raw waste landfilled in the aerobic and anaerobic test cells was determined as $73.1 \%$. The volatile solids content (dry matter-ash content) corresponds closely with the typically expected biodegradable organics in an MSW stream of $60-70 \%$ (Owens and Chynoweth, 1993). Considerable part of volatile solids was removed in the first 200 days by decomposition of easily degradable organic matter content in $\mathrm{A} 1$ and $\mathrm{A} 2$ test cells. VS content of solid wastes in $A 1$ and $A 2$ test cells were determined as $58.6 \%$ and $51.1 \%$ after 200 days of operation. In $A 1$ and $A 2$ test cells VS removal efficiencies were found to be $32.4 \%$ and $38.9 \%$, respectively on day 400 . The results show that aeration (forced or natural) accelerates VS removal in the test cells.

The variation of TOC shows similarity with the variation of VS content and total carbon obtained by elemental analysis. The TOC value of the raw waste was determined to be $38.7 \%$. After 400 days of operation TOC value of the solid waste samples collected from A1, A2, AN1 and AN2 test cells were found to be 23.4, 20.7, 30.5 and $26.1 \%$, respectively. It can be seen from Table 3 that the considerable ratio of TOC removal was achieved in 200 days of the operation in aerobic test cells. It can be mentioned that there is a significant decrease in TOC values of the waste samples collected from anaerobic test cells.

Initial TKN values of the waste before landfilling was determined as $2.2 \%$. In aerobic test cells TKN values of the samples increased by time. This can be explained by mass loss. TKN values were found to be $3.1 \%$ and $3.6 \%$ after 400 days of operation in aerobic test cells. No cinsiderable change was observed in TKN values of the samples collected from anaerobic test cells.

$\mathrm{C}: \mathrm{N}$ ratio is a common indicator of the availability of compounds for microbial use. For degradation to proceed efficiently, microorganisms require specific nutrients in an available form, adequate concentration, and proper ratio. Either $\mathrm{C}$ or $\mathrm{N}$ is usually the limiting factor for efficient decomposition. Microorganisms require $\mathrm{C}$ as an energy source, also need $\mathrm{C}$ and $\mathrm{N}$ to synthesize proteins, build cells and reproduce. High $\mathrm{C} / \mathrm{N}$ ratios (high $\mathrm{C}$ and low $\mathrm{N}$ levels) inhibit the growth of microorganisms.
Microorganisms utilize $\mathrm{C}$ and $\mathrm{N}$ at a ratio of $30: 1$. Low $\mathrm{C} / \mathrm{N}$ ratios result in nitrogen volatilization in the form of ammonia. At $\mathrm{C} / \mathrm{N}$ ratios exceeding 50:1, the process slows because of rapid cell growth and depletion of available $\mathrm{N}$, resulting in reduced cellular growth (Epstein, 1997).

$\mathrm{C} / \mathrm{N}$ ratio is especially significant for aerobic degradation processes. For rapid degradation initial $\mathrm{C} / \mathrm{N}$ ratio is suggested to be in the range of 20-35 (Epstein, 1997; Graves and Hattamer, 2000).

In some cases $\mathrm{C} / \mathrm{N}$ ratio can be deceptive. For instance lignin has high $\mathrm{C}$ content but is not a good energy source (Aydin and Kocasoy, 2002). Researchers; Arıkan (2003), Aydın and Kocasoy (2002) and Tosun (2003) used (C/N) final $/(C / N)_{\text {Initial }}$ parameter as a stabilization indicator. In this study, $\mathrm{C} / \mathrm{N}$ ratio was determined as 17.6 at the beginning of the study. Since $C / N$ ratio is relatively low at the beginning of the degradation, $(C / N)_{\text {final }} /(C / N)_{\text {initial }}$ parameter is used. $\mathrm{C} / \mathrm{N}$ ratio decreased rapidly by time. The acceleration is high in the first 200 days of landfilling.

$\mathrm{C} / \mathrm{N}$ ratio of $\mathrm{A} 1$ test cell on day 200 and on day 400 was determined as 9.4 and 7.5 , respectively. $\mathrm{C} / \mathrm{N}$ ratio of $\mathrm{A} 2$ test cell on day 200 and 400 was measured as 7.6 and 5.7, respectively. $(\mathrm{C} / \mathrm{N})_{\text {final }} /(\mathrm{C} / \mathrm{N})_{\text {initial }}$ ratio of solid waste samples disposed in $\mathrm{A} 1$ test cell was determined as 0.43 which is in the range of allowable values concluded in previous studies (Aydın and Kocasoy, 2002; Arıkan, 2003; Tosun, 2003). $(\mathrm{C} / \mathrm{N})_{\text {final }} /(\mathrm{C} / \mathrm{N})_{\text {Initial }}$ ratio of waste samples landfilled in A2 test cell was determined as 0.33 . It can be concluded that this value was found to be below the recommended limit in literature because of the high nitrogen content.

\subsubsection{Stability index (SI)}

$\mathrm{SI}$ is a measure of oxygen uptake rate and is dependent on aerobic biological activity of the compost which is measured as $\mathrm{mg}\left(\mathrm{O}_{2}\right) / \mathrm{g}(\mathrm{VS}) / \mathrm{h}$. Epstein (1997) and Das et al. (2002) concluded that aerobic organic compost with a SI less than $1.0 \mathrm{mg} \mathrm{O}_{2} / \mathrm{g}(\mathrm{VS}) / \mathrm{h}$ may be considered stable and 1.0-1.5 mg $\mathrm{O}_{2} / \mathrm{g}(\mathrm{VS}) / \mathrm{h}$ moderately stable. Aerobically unstable compost typically exhibit SI greater than $2.0 \mathrm{mg}$ $\mathrm{O}_{2} / \mathrm{g}(\mathrm{VS}) / \mathrm{h}$.

SI analysis results of solid waste samples of aerobic test cells are given in Table 3. As can be seen from Table 3, after 200 days of operation, SI values of solid waste samples obtained from $\mathrm{A} 1$ and $\mathrm{A} 2$ test cells were determined as 1.82 and $1.54 \mathrm{mg}\left(\mathrm{O}_{2}\right) / \mathrm{g} \quad(\mathrm{VS}) / \mathrm{h}$, respectively, indicating stabilization is not completed. $\mathrm{SI}$ value of the sample of $A 2$ test cell is lower than that of the sample of $A 1$ test cell because of the higher aeration rate. On day 400, SI values of solid waste samples of A1 and A2 test cells were determined as 1.42 and $1.27 \mathrm{mg}\left(\mathrm{O}_{2}\right) / \mathrm{g}$ (VS)/h, respectively. These results indicate that waste disposed in aerobic test cells are moderately stabilized after 400 days of operation. SI value of the waste of A2 test cell simulating aerobic degradation with forced aeration, is closer to $1 \mathrm{mg}$ $\mathrm{O}_{2} / \mathrm{g}(\mathrm{VS}) / \mathrm{h}$ indicating that aeration accelerates degradation. 
Table 3. The variation of SI and VS parameters in A1 and A2 test cells

\begin{tabular}{ccccc}
\hline \multirow{2}{*}{$\begin{array}{c}\text { Time, } \\
\text { day }\end{array}$} & $\begin{array}{c}\text { VS } \\
\text { (\%) }\end{array}$ & $\begin{array}{c}\text { SI } \\
\text { (mg O }\end{array}$ /g VS/h) & $\begin{array}{c}\text { VS } \\
\text { (\%) }\end{array}$ & $\begin{array}{c}\text { A2 } \\
\text { (mg O } / \text { /g VS/h) }\end{array}$ \\
\hline 200 & 58.6 & 1.82 & 51.1 & 1.54 \\
\hline 400 & 49.9 & 1.42 & 44.7 & 1.27 \\
\hline
\end{tabular}

\subsubsection{Biochemical methane potential (BMP)}

BMP is a valuable, quick and inexpensive method for determination of the potential extent and rate of conversion of biomass and wastes to $\mathrm{CH}_{4}$. BMP test was first applied by Owen et al. (1979) and modified by Owens and Chynoweth (1993). BMP tests have been applied to various types of wastes by several authors (Mehta, 2000; Demir et al., 2004; Gunaseelan, 2004; Raposo et al., 2006; Davidsson et al., 2007; Francois et al., 2007; Carneiro et al., 2008; Neves et al., 2008; Zhu et al., 2009; Bilgili et al., 2009).

The BMP assay was applied to the waste samples of AN1 and $\mathrm{AN} 2$ test cells. Cumulative $\mathrm{CH}_{4}$ values for $10 \mathrm{~g}$ dry raw waste are given in Figure 3. It is observed from the figure that initial BMP value was 3.32 I for $10 \mathrm{~g}$ dry waste.

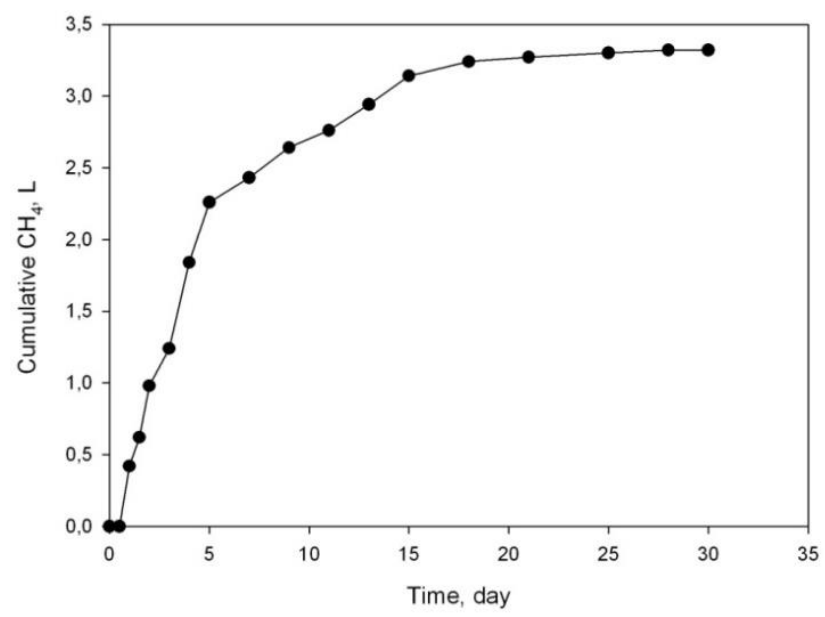

Figure 3. Cumulative $\mathrm{CH}_{4}$ generation for $10 \mathrm{~g}$ dry raw waste

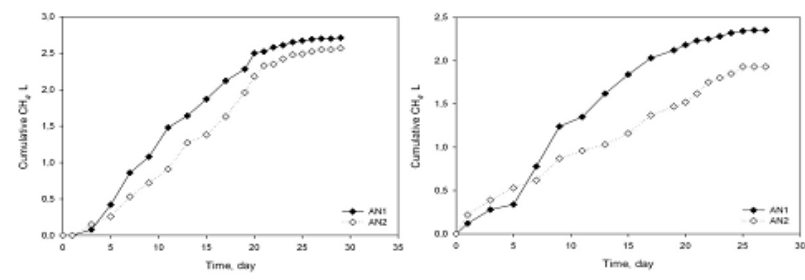

Figure 4. BMP for $10 \mathrm{~g}$ dry solid waste samples of AN1 and AN2 test cells on day 200 and 400

BMP values of waste samples excavated from AN1 and AN2 test cells on day 200 and 400 are shown in Figure 4. After 200 days of operation, BMP values for $10 \mathrm{~g}$ dry solid waste samples of AN1 and AN2 test cells were determined as $2.71 \mathrm{~L}$ and $2.57 \mathrm{~L}$, respectively. BMP values for $10 \mathrm{~g}$ dry solid waste samples of AN1 and AN2 test cells were determined as $2.35 \mathrm{~L}$ and $1.93 \mathrm{~L}$ on day 400 , respectively.
Results of BMP assay applied to the solid waste landfilled in the anaerobic test cells are given in Table 4.

Table 4. Results of BMP assay

\begin{tabular}{ccc}
\hline \multirow{2}{*}{ Time, day } & \multicolumn{2}{c}{ BMP values $\left(\mathrm{L} \mathrm{CH}_{\mathbf{4}} / \mathbf{1 0}\right.$ g dry waste) } \\
\cline { 2 - 3 } & AN1 & AN2 \\
\hline 0 & 3.32 & 3.32 \\
200 & 2.71 & 2.35 \\
400 & 2.57 & 1.93 \\
\hline
\end{tabular}

Assuming waste degradation occurs with respect to first order reaction rate, waste degradation rate coefficients of AN1 and AN2 test cells are calculated in respect to BMP results. First order kinetic coefficients of the waste samples taken from landfill body were calculated and the results are given in Table 5 . Mean value of kinetic coefficients for AN1 and AN2 test cells are 0.340 year $^{-1}$ and 0.478 year $^{-1}$, respectively. From these results it can be concluded that leachate recirculation increases waste degradation rate.

Table 5. First order kinetic coefficients for BMP in anaerobic test cells

\begin{tabular}{ccc}
\hline Time $(\mathbf{t})$, year & $\mathbf{k}_{\mathrm{AN} 1}$, year $^{-1}$ & $\mathbf{k}_{\text {AN2 }}$, year $^{-1}$ \\
\hline 0 & - & - \\
\hline 0.55 & 0.367 & 0.462 \\
\hline 1.10 & 0.314 & 0.493 \\
\hline Mean value & 0.340 & 0.478 \\
\hline
\end{tabular}

\subsection{Landfill gas components}

During solid waste stabilization significant portions of organic wastes are ultimately converted to gaseous end products. The rate of gas production is a function of waste composition, climate, moisture content, particle size and compaction, nutrient availability and buffering capacity. Landfill gas is typically $40-60 \%$ methane with carbon dioxide and trace gases such as hydrogen sulfide, water vapour, hydrogen and various volatile organic compounds comprising the balance (Reinhart, 1993; Themelis and Ulloa, 2007).

In aerobic test cell (A2), aeration rate was regulated by monitoring landfill gas components of $\mathrm{CO}_{2}, \mathrm{O}_{2}$ and $\mathrm{CH}_{4}$ to avoid methane formation in the test cell and to keep $\mathrm{CH}_{4}$ and $\mathrm{O}_{2}$ percentage of landfill gas below the limits given in literature (Binner et al., 2003). In semi-aerobic test cell (A1) it was determined that $\mathrm{O}_{2}$ amount was sufficient and $\mathrm{CH}_{4}$ ratio of landfill gas was below the value of $8 \%$ in all of the measurements. The variations of $\mathrm{CH}_{4}, \mathrm{CO}_{2}, \mathrm{O}_{2}$ ve $\mathrm{H}_{2} \mathrm{~S}$ landfill gas components of AN1 and AN2 test cells are illustrated in Figure 5.

As can be seen from Figure 5, the initial $\mathrm{CH}_{4}$ amount of AN1 and AN2 test cells, landfill gas were determined in the range of $0-20 \%$. No significant difference between $\mathrm{CH}_{4}$ ratios of AN1 and AN2 test cells were observed in the first 100 days. After 100 days of operation, $\mathrm{CH}_{4}$ content of landfill gas of AN2 test cell began to increase, and reached to the ratio of $40 \%$ on day 150 , and $50 \%$ on day 200 . No significant change was observed after this time untill the end of the study. $\mathrm{CH}_{4}$ content of landfill gas from AN1 test cell was determined to be $40-45 \%$ after day 250 and no considerable changes were observed till the end of the 
study. These results show that waste decomposition rate in AN2 test cell is higher and thereby the time required to reach methanogenic phase is shorter.
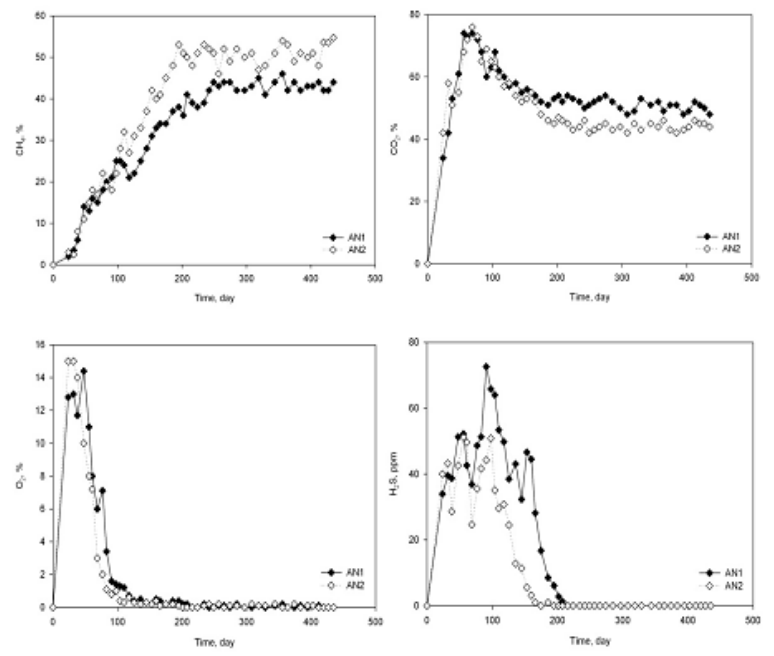

Figure 5. The variation of landfill gas components in AN1 and AN2 test cells

As can be seen from Figure $5, \mathrm{CO}_{2}$ ratios of landfill gas in AN1 and AN2 test cells were determined in the range of $50-70 \%$. After reaching maximum values, $\mathrm{CO}_{2}$ amount of landfill gas generated in AN1 and AN2 test cells decreased to $50 \%$ and $45 \%$ on day 200 , respectively. No considerable change was observed after that time. During the initial aerobic phase, oxygen present in the void spaces of the freshly buried refuse is rapidly consumed, resulting in the production of $\mathrm{CO}_{2}$ and maybe an increase in waste temperature. The aerobic phase in a landfill lasts only a few days because oxygen is not replenished once the waste is covered. During the aerobic phase, the waste is not typically at field capacity (Barlaz et al., 1992). Most leachate produced during this phase results from the release of moisture during compaction as well as short-circuiting of precipitation through the buried refuse. As oxygen sources are depleted, the waste becomes anaerobic, which supports fermentation reactions (Kjeldsen et al., 2002).

As can be seen from Figure $5, \mathrm{O}_{2}$ content of the landfill gas of AN1 and AN2 test cells were determined about $15 \%$ at the beginning of the degradation. After the operation time of 120 days as anaerobic decomposition begins $\mathrm{O}_{2}$ content of the landfill gas decreases to $1 \%$ and on day 200 the entire $\mathrm{O}_{2}$ in the landfill is depleted.

Under oxidizing conditions in the landfill body, $\mathrm{SO}_{4}^{-2}$ concentration in the aqueous phase is high while $\mathrm{H}_{2} \mathrm{~S}$ content in the gas phase is low. As the reducing conditions become dominant, $\mathrm{H}_{2} \mathrm{~S}$ content of landfill gas generated in AN1 and AN2 test cells increased and after 50-200 days of operation $\mathrm{H}_{2} \mathrm{~S}$ content was determined in high levels (Figure 5). The increase of $\mathrm{H}_{2} \mathrm{~S}$ content can be explained by the convertion of $\mathrm{SO}_{4}{ }^{-2}$ to $\mathrm{H}_{2} \mathrm{~S}$ rapidly. $\mathrm{H}_{2} \mathrm{~S}$ content in AN1 and AN2 test cells was depleted after 220 and 180 days, respectively.

\subsection{Temperature variations}

Temperature probes were located at 1.0, 1.5, 2.0 and $3.0 \mathrm{~m}$ depths from the top of the waste to monitore temperature variation in each test cell. The average temperature values determined by the temperature probes in each test cell are depicted in Figure 6. Because of the significant differences in energy balance of aerobic and anaerobic degradation processes, considerable differences in temperature variation in landfill body of aerobic and anaerobic test cells were also observed.

The temperature in the landfill body of semi-aerobic test cell (A1) was measured as $40{ }^{\circ} \mathrm{C}$ at the beginning of the study. After 2 months of operation, temperature reached to the maximum value of $48{ }^{\circ} \mathrm{C}$. Because of the rainy and cold season, temperature began to decrease after that time but it was not observed below $35{ }^{\circ} \mathrm{C}$ till the end of the study. In the spring months it is determined that the temperature increased to the range of $40-45{ }^{\circ} \mathrm{C}$ and no considerable change was observed during the study.

The initial temperature determined in the aerobic test cell determined in the range of $45-50{ }^{\circ} \mathrm{C}$. The temperaure of the landfill body increased and reached to its maximum values of $50-60{ }^{\circ} \mathrm{C}$ in $\mathrm{A} 2$ test cell. After the decrease in winter months, increase in temperatures measured in four different dephts was observed. The temperature measured in A2 test cell after cold months till the end of the study ranged between $45-55^{\circ} \mathrm{C}$.

The temperature variations in anaerobic test cells were determined in limited ranges. An increase in waste temperature in the landfill body was observed, during the initial aerobic phase. After the depletion of the present oxygen in the void spaces of the waste mass, temperature decreased around $30^{\circ} \mathrm{C}$. There was no significant change till the end of the study after that time.
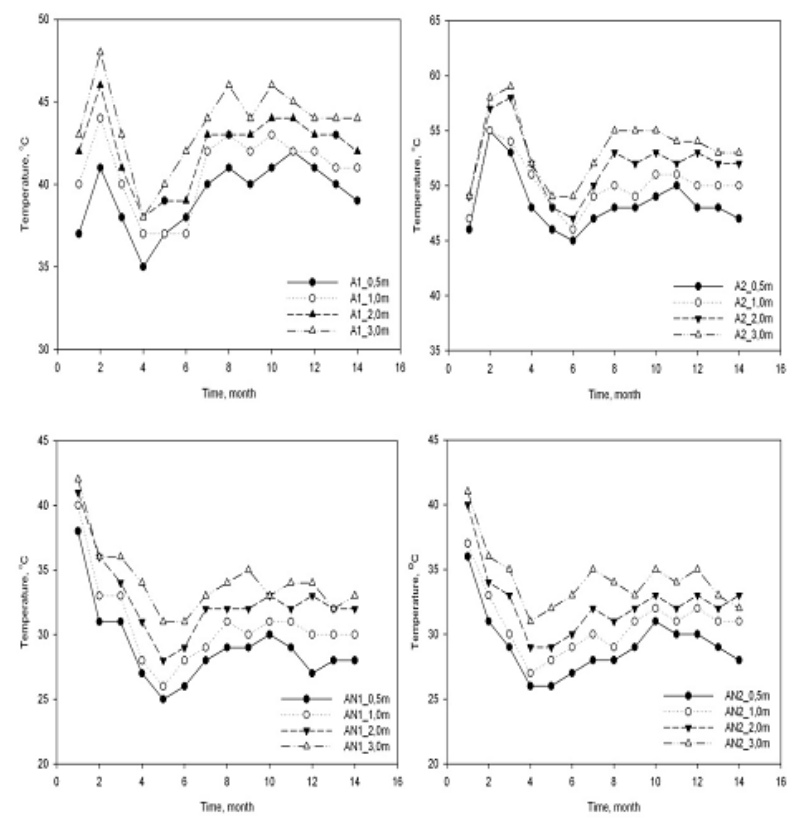

Figure 6. The variation of temperature in the landfill body 


\subsection{Topographic measurements}

The rate of landfill settlement mainly depends on the waste composition, operational conditions and factors affecting biodegradation of landfill waste (Wall and Zeiss, 1995). All factors that accelerate the decomposition of biological processes (organic matter content, temperature, moisture content, $\mathrm{pH}$, etc.), but also increases the rate of settlement. However, the amount of settlement may not be uniform in various regions of the landfill due to the effective decompositon processes. Most of the settlement of solid waste occures in the first few years after landfilling operation.

There were 14 points in each cell used for the topographic measurements. The first measurements were taken after the closing of the test cells. The second measurements were taken after 12 months of operation (data not shown). The amount of settlement in A1, A2, AN1, and AN2 test cells were determined to be 24.0, 32.6, 11.0 and $20.4 \mathrm{~cm}$, respectively. It can be seen from the tables that settlement observed in A2 test cell is greater than that of the other test cells. Assuming that the mechanical settlement rates are equal to each other in all test cells, the difference in the settlement occured in A2 test cell can be explained by the accelerated degradation of solid waste.

\section{Conclusion}

In this study, alternative landfilling methods for accelerating solid waste stabilization in landfills are investigated by the means of solid waste characteristics, landfill gas composition, temperature variation and settlement amount in the landfill body.

From the general findings of this study, it can be concluded that;

- Aeration in municipal solid waste landfills is a viable management option for the accelerated stabilization of a waste matrix. Aerobic test cells exhibit a higher rate of biodegradation, and achieve a high waste volume reduction in a relatively short duration than anaerobic test cells. The acceleration of MSW biodegradation not only decreases the life of the landfill, but also reduces overall monitoring costs incurred with post-closure of landfill sites.

- Semi-aerobic landfilling technology is a viable method to be used in developing countries such as Turkey, based on the results of the cost benefit analysis of the entire implementation process, from the development stage to final closure.

- The anaerobic landfill shows the highest levels of all pollutional parameters, with high concentrations. However; leachate recirculation to anaerobic landfills accelerates the rate of biological degradation of solid waste, reduces the level of concentration of contaminants and increases the rate of landfill gas generation.
- Aeration and leachate recirculation enhance the settlement of the solid waste landfilled and result in the recovery of landfill air space, which can be utilized for landfilling more solid waste.

\section{Acknowledgements}

This research has been supported by The Scientific and Technological Research Council of Turkey (TUBITAK - CAYDAG) (Project Number: 106Y228) Ankara-Turkey. The authors wish to acknowledge Istanbul Environmental Managemet Industry and Trade Inc. (ISTAC) for their support during the study.

\section{References}

Arıkan O.A. (2003), Aerobic and Anaerobic Composting of Different Organic Solid Wastes (in Turkish), I.T.U Institute of Science, Environmental Engineering, Ph.D.Thesis, Istanbul.

Aydın G.G. and Kocasoy G. (2002), Investigation of appropriate initial composting and aeration method for co-composting of yard waste and market wastes. (Paper presented at Appropriate Environmental and Solid Waste Management and Technologies for Developing Countries, ISWA '02 istanbul)

Aziz S.Q., Aziz H.A., Yusoff M.S., Bashir M.J. and Umar M. (2010), Leachate characterization in semi-aerobic and anaerobic sanitary landfills: A comparative study, Journal of Environmental Management, 91, 2608-2614.

Barlaz M.A., Ham R.K. and Schaefer D.M. (1992), Microbial, chemical and methane production characteristics of anaerobically decomposed refuse with and without leachate recycling, Waste Management and Research, 10(3), 257-267.

Bashir M.J.K., Aziz H.A., Yusoff M.S. and Adlan M.N. (2010), Application of response surface methodology (RSM) for optimization of ammoniacal nitrogen removal from semiaerobic landfill leachate using ion exchange resin, Desalination, 254, 154-161.

Bilgili M.S. (2006), Katı Atık Düzenli Depo Sahalarında Atıkların Aerobik ve Anaerobik Ayrışması Üzerine Sızıntı Suyu Geri Devrinin Etkileri, Doktora Tezi, Yıldız Teknik Üniversitesi Fen Bilimleri Enstitüsü, İstanbul.

Bilgili M.S., Demir A. and Ozkaya B. (2007), Influence of leachate recirculation on aerobic and anaerobic decomposition of solid wastes, Journal of Hazardous Materials, 143, 177-183.

Bilgili M.S., Demir A. and Varank G. (2009), Evaluation and modeling of biochemical methane potential (BMP) of landfilled solid waste: A pilot scale study, Bioresource Technology, 100, 4976-4980.

Binner E., Lechner P., Erdin E. and Alten A. (2003), Composting of bioorganic waste originating from Vienna (in Turkish). http://web.deu.edu.tr/erdin/pubs/viyanabiyojenatik.pdf.

Borglin S.E., Hazen T.C., Oldenburg C.M. and Zawislanski P.T. (2004), Comparison of aerobic and anaerobic biotreatment of municipal solid waste, Journal of Air Waste Management Association, 54, 815-822.

Carneiro T.F., Pérez M. and Romero L.I. (2008), Thermophilic anaerobic digestion of source-sorted organic fraction of municipal solid waste, Bioresource Technology, 99, 67636770.

Chan G.Y.S., Chub L.M. and Wong M.H. (2002), Effects of leachate recirculation on biogas production from landfill codisposal of municipal solid waste, sewage sludge and marine sediment, Environmental Pollution, 118, 393-399. 
Cossu R., Raga R. and Rossetti D. (2003), The PAF model: an integrated approach for landfill sustainability, Waste Management, 23(1), 37-44.

Das C., Smith M.C., Gattie D.K. and Boothe D.D.H. (2002), Stability and quaility of municipal solid waste compost from a landfill aerobic bioreduction process, Advances Environmental Research, 6, 401-409.

Davidsson A., Gruvberger C., Christensen T.H., Hansen T.L. and Jansen J.C. (2007), Methane yield in source-sorted organic fraction of municipal solid waste, Waste Management, 27, 406-414.

Davis M.L. and Cornwell D.A. (2008), Introduction to Environmental Engineering. International Edition, fourth ed. McGraw Hill, New York.

Demir A., Bilgili M.S. and Ozkaya B. (2004), Effect of leachate recirculation on refuse decomposition rates at landfill site: a case study. International Journal of Environment and Pollution, 21, 175-187.

Demir I., Altinbas M., Arıkan O.A. and Öztürk İ. (2001), Aerobic composting of anise wastes from beverage (rakı) industry. (Paper presented at Proceedings of the Eigth International Waste Management and Landfill Symposium, Sardinia, Italy)

Dong L., Wang Q., Li Y. and Huang S.H. (2000), The research of acceleration for stabilization in the landfill site, China Environmental Sciences, 20, 461-464.

Epstein E. (1997), The Science of Composting, Technomic Publishing Company, Inc.

Francois V., Feuillade G., Matejka G., Lagier T. and Skhiri N. (2007), Leachate recirculation effects on waste degradation: study on columns, Waste Management, 27(125), 1259-1272.

Graves R.E. and Hattemer G.M. (2000). Environmental Engineering National Engineering Handbook, United States Department of Agriculture, Natural Resources Conservation Service.

Gunaseelan V.N. (2004), Biochemical methane potential of fruits and vegetable solid waste feedstocks, Biomass Bioenergy, 26, 389-399.

Hudgins M. and Harper S. (1999), Operational characteristics of two aerobic landfill systems. Proceedings of the Seventh International Waste Management and Landfill Symposium, Italy.

Kim Y. and Yang G.J. (2002), A novel design for anaerobic chemical oxygen demand and nitrogen removal from leachate in a semiaerobic landfill, Air Waste Management Association, 52, 1139-1152.

Kjeldsen P., Barlaz M.A., Rooker A.P., Baun A., Ledin A. and Christensen T.H. (2002), Present and long-term composition of MSW landfill leachate: a review, Environmental Science \& Technology. 32, 297-336.

Marticorena C.L., Williams K.A., Deber C.M., Reithmeier R.A.F. (1993), Non-random distribution of amino acids in the transmembrane segments of human type I single span membrane proteins, Journal of Molecular Biology, 229, 602608.

Mehta R., Barlaz M.A., Yazdani R., Augenstein D., Bryars M., Sinderson L. (2002), Refuse Decomposition in the Presence and Absence of Leachate Recirculation, Journal of Environmental Engineering, ASCE, 128 (3), 228-236.

Mehta R.C., Barlaz M.A. and Yazdani R. (2002), Refuse decomposition in the presence and absence of leachate recirculation, Journal of Environmental Engineering, 128, 228-236.

Methods of Soil Analysis Part 3, Chemical Methods (1996), Sparks D.L. (ed.), Soil Science of America, Inc.

Mohee R., Unmar G.D., Mudhoo A. and Khadoo P. (2008), Biodegradability of biodegradable/degradable plastic materials under aerobic and anaerobic conditions, Waste Management, 28(9),1624-1629.

Nakasaki K., Yaguchi H., Sasaki Y. and Kubota H. (1993), Effects of $\mathrm{pH}$ control on composting garbage, Waste Management and Research, 11, 117-125.

Neves L., Goncalo E., Oliveira R. and Alves M.M. (2008), Influence of composition on the biomethanation potential of restaurant waste at mesophilic temperatures, Waste Management, 28, 965-972.

Onay O.O. and Pohland F.G. (1998), In situ nitrogen management in controlled bioreactor landfills, Water Research, 32, 13831392

Owen W.F., Stuckey D.C., Healey J.B., Young L.Y. and McCarty P.L. (1979), Bioassay for monitoring biochemical methane potential and anaerobic toxicity, Water Resources, 13, 485492.

Owens J.M. and Chynoweth D.P. (1993), Biochemical methane potential of MSW components, Water Science and Technology, 27, 1-14.

Öztürk M. (1993), Degradation of acetate, propionate, and butyrate under shock temperature, Jouornal of Environmental Engineering, 119, 321-331.

Pohland F.G. and Al-Yousifi B. (1994), Design and operation of landfills for optimum stabilization and biogass production, Water Science Technology, 30, 117-124.

Pohland F.G. and Kim J.C. (1999), In situ anaerobic treatment of leachate in landfill bioreactors, Water Science Technololgy, 40(8), 203-210

Pohland F.G. and Kim J.C. (2000), Microbially mediated attenuation potential of landfill bioreactor systems, Water Science and Technology, 41 (3), 247-254.

Price G.A., Barlaz M.A. and Haterb G.R. (2003), Nitrogen management in bioreactor landfills, Waste Management, 23, 675-688.

Qifei H., Yufei Y., Xiangrui P. and Qi W. (2008), Evolution on qualities of leachate and landfill gas in the semi-aerobic landfill, Journal of Environmental Science, 20, 499-504.

Raposo F., Banks C.J., Siegert I., Heaven S. and Borja R. (2006), Influence of inoculum to substrate ratio on the biochemical methane potential of maize in batch tests, Process Biochemistry, 41, 1444-1450.

Read A.D., Hudgins M. and Phillips P. (2001a), Perpetual landfilling through aeration of the waste mass; lessons from test cells in Georgia (USA), Waste Management, 21, 617-629.

Read A.D., Hudgins M., Harper S., Phillips P.and Morris J. (2001b), The successful demonstration of aerobic landfilling the potential for a more sustainable solid waste management approach, Conservatrice Recycling, 32, 115146.

Reinhart D.R. (1993), A Review of recent studies on the sources of hazardous compounds emitted from solid waste landfills: A U.S. experience, Waste Management and Research, 11, 257-268. 
Reinhart D.R., McCreanor P.T. and Townsend T. (2002), The bioreactor landfill: its status and future, Waste Management and Research, 20, 172-186.

Rich C., Gronow J. and Voulvoulis N. (2008), The potential for aeration of MSW landfills to accelerate completion, Waste Management, 28, 1039-1048

Ritzkowski M., Walker B., Kuchta K., Raga R. and Stegmann R. (2016), Aeration of the Teuftal landfill: Field scale concept and lab scale simulation, Waste management, 55, 99-107.

Shimaoka T., Matsufuji Y. and Hanashima M. (2000), Characteristic and mechanism of semi-aerobic landfill on stabilization of solid waste. 1st Intercontinental Landfill Research Symposia, December 11-13, Lulea, Sweden.

Shou-liang H., Bei-dou X., Hai-chan Y., Shi-lei F., Jing S. and Hongliang L. (2008), In situ simultaneous organics and nitrogen removal from recycled landfill leachate using an anaerobicaerobic process, Bioresource Technology, 99, 6456-6463.

Tchobanoglous G., Theisen H. and Vigil S.A. (1993), Integrated Solid Waste Management: Engineering Principles and Management Issues, McGraw Hill, Inc., U.S.A.

Themelis N.J. and Kim Y.H. (2002), Material and energy balances in a large-scale aerobic bioconversion cell, Waste Management Research, 20, 234-242.

Themelis N.J. and Ulloa P.A. (2007), Methane generation in landfills, Renewable Energy, 32, 1243-1257.

Tong H., Yin K., Giannis A., Ge L. and Wang J.Y. (2015), Influence of temperature on carbon and nitrogen dynamics during in situ aeration of aged waste in simulated landfill bioreactors, Bioresource Technology, 192, 149-156.

Tosun i. (2003), Rose Residual Compostable with Municipal Solid Waste (in Turkish). Y.T.U Institute of Science, Environmental Engineering, Phd Thesis, Y.T.U., Istanbul.

Townsend T.G., Powell J., Jain P., Xu Q., Tolaymat T. and Reinhart D. (2015), Sustainable Practices for Landfill Design and Operation. Springer, Series: Waste Management Principles and Practice.

Wall D. and Zeiss C. (1995). Municipal landfill biodegradation and settlement, Journal of Environmental Engineering, 121, 214223.

Yasushi M. and Masataka H. (1997), Characteristic and mechanism of semi-aerobic landfill on stabilization of solid waste, Proceedings of the first Korea-Japan Society of Solid Waste Management, pp. 87-94.

Zhu B., Gikas P., Zhang R., Lord J., Jenkins B. and Li X. (2009), Characteristics and biogas production potential of municipal solid wastes pretreated with a rotary drum reactor. Bioresource Technology, 100, 1122-1129. 